January-June 2019

Volume: 9, No: 1, pp. $43-62$

ISSN: 2046-4436

e-ISSN: 2046-4444

https://www.tplondon.com/bordercrossing/

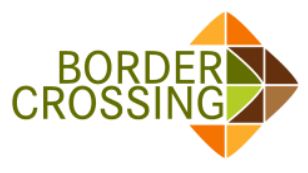

Received: 4 July 2019 Accepted: 3 Aug. 2019

DOI: https://doi.org/10.33182/bc.v9i1.819

\title{
Bordering in Europe: Differential Inclusion
}

Peter O’Brien ${ }^{ \pm}$

\begin{abstract}
Borders exist and operate not only at formal frontiers but also outside and within European countries. Furthermore, borders both exclude and include migrants. This article advances the theory of differential inclusion. It provides a more nuanced understanding of processes of bordering that comprehends irregular migration as a phenomenon that is not only officially denounced and combatted but also unofficially tolerated and facilitated by European states. The analysis reveals that differential inclusion is transforming citizenship in Europe away from officially desired equality toward unofficially tolerated stratification. Employing Foucault's notion of "assemblage", the article also seeks to shed light on not only whose interests are undermined but also on whose interests are served by differential inclusion.
\end{abstract}

Keywords: Irregular migration; refugees; borders; differential inclusion; Europe.

\section{Introduction}

Many scholars now challenge the popular notion that borders are designed primarily to keep out (unwanted) foreigners. Critical Border Studies draw attention to the varied ways in which borders actually enable and even encourage the entrance of "foreigners" (Düvell, 2006; Mezzadra and Neilson, 2013; Squire, 2011). Moreover, this includes not only officially desirable border-crossers like legal immigrants and tourists, but also officially undesirable or "illegal" migrants. Indeed, the number and prevalence of the undocumented have grown to such an extent that scholars now theorise the "irregularization of migration" (Jansen, Celikates and de Bloois, 2015) or the "regularization of irregularity" (O’Brien, 2016: 85). Sassen (2014: 23) avers that "unauthorized immigration has emerged as a generalized fact in all Western economies in the post World War II era". De Genova (2015: 8) characterises "Irregularity... [as] a very regular and predictable feature of the routine and systematic functioning of border and immigration enforcement regimes".

Despite their regular inclusion into designation lands, undocumented migrants have an inferior, precarious legal status compared to legal migrants and citizens. Furthermore, most (not all) undocumented migrants suffer an underprivileged socio-economic existence because their uncertain legal status makes them highly susceptible to exploitation (Anderson, 2013; Fedyuk and Stewart, 2018a; Kraler, 2019, Sainsbury, 2012; Squire, 2011). This article advances the theory of differential inclusion (Mezzadra and Neilson, 2013). Different degrees of citizenship and residency rights, ranging from fully legal to semi-legal to illegal(ised), translate into significant political and socioeconomic stratifications. Surveying the vast literature on immigration in Europe, the article differentiates between three types of migration -- regular, irregular and blocked - and underscores the gravely different consequences of each for migrants.

${ }^{ \pm}$Peter O’Brien, Professor of Political Science at Trinity University, 1 Trinity Place, San Antonio, Texas 78212, United States. E-mail: pobrien@trinity.edu. 
The conceptual lens of differential inclusion rightly focuses attention on the millions of "losers", that is, those adversely affected by the phenomenon, although the "victims" are hardly powerless to resist their oppression (Squire, 2011). This understandable focus, however, often obscures the "winners," who are actually as integral to the practice and persistence of differential inclusion as the losers. The essay employs Foucault's (2007: 311) notion of "assemblage" to shed light on those persons and institutions that (most) benefit from differential inclusion. The conceptual lenses of differential inclusion and assemblage reveal a Europe, in which the model and ideal of citizenship are transforming from ones based on equality to ones based on stratification. The transformation, furthermore, gives cause to reconceptualise what is meant by sovereignty, citizenship and, indeed, Europe itself.

\section{Border Theory}

A few additional theoretical remarks about bordering are in order. Borders are neither permanent nor firm; rather, they are fluid and malleable. Borders and border enforcement do not exist merely on the physical frontiers of sovereign states. They can exist beyond the physical frontier when a government "externalizes" its border by persuading other states to exercise border control on its behalf (Frelick et al., 2016: 197). Borders also exist within a country's formal physical frontiers (Balibar, 1998; Vaughan-Williams, 2008). They are present wherever police seize, detain, deport or even patrol migrants. As Fabini (2017: 49) observes, "every police officer is a border". De facto bordering also takes place when employers, say, threaten to expose disobedient workers who lack papers or when the undocumented forego taking advantage of state services to which they are entitled for fear of being detected (Sainsbury, 2012; Triandafyllidou, 2010). Because borders are typically contested both by groups wanting to loosen or to tighten them, categories of inclusion and exclusion frequently change (Squire, 2011; Vertovec 2016). Mass amnesties transpire that legalise large numbers of the undocumented. At the same time, persons regularly move from legal to illegal status due to visa expirations and violations.

Migrations and migrants transform societies. Indeed, they are constitutive, for it is only possible to define who are citizens (insiders) by simultaneously defining/marking who are not citizens (outsiders). Borders are thus both physical and performative (Agamben, 2000: 32). Statecentric theories of citizenship exhibit an ontological and political bias toward stasis. Emigrants are those who are exiting (abandoning) their homeland, while immigrants are understood as those entering (needing to adapt to) a new homeland. Both categories of mobile people are conceptualised in conventional political theory as "failed citizens" of sorts not deserving the same rights as stationary insiders (Nail, 2015: 3; also Isin, 2018). Although conventional theory posits a stable polity and people that emigrants leave and immigrants enter, the fact of the matter is that migrants significantly change (if only gradually) the way societies function and often fundamentally challenge definitions of citizenship. "The migrant not only undergoes an extensive movement but also affects an intensive or qualitative social movement of the whole of society itself" (Nail, 2015: 13). For example, the differential inclusion of documented and undocumented migrants changes the nature and experience of citizenship by creating multiple grades or levels of de facto citizenship a development that citizenship scholars seek to grasp through concepts such as "informal citizens" (Sassen, 2014: 15), "semi-citizens" (Cohen, 2009), or "subcitizens" (Chauvin and BarcésMascareñas, 2012: 251). Likewise, the management of migrants and migration profoundly transform sovereignty. When European governments effectively compel Middle Eastern and African states to process migrants and refugees in their countries before they reach Europe, these 
non-European states become sovereign agents of Europe typically, however, without the kind of democratic accountability common in well-functioning democracies. Something similar occurs when states delegate authority to manage migration to non-governmental organizations whose chief goals may be, say, profit rather than exercising the democratic will of the people.

\section{Regular Migration}

Before turning to undocumented migrants, it makes sense to add a few brief remarks about the documented, for not all legally resident aliens are equal. In other words, legal aliens too can and do fall victim to differential inclusion. For example, many migrant workers supplied by foreign subcontractors to businesses in northern Europe work under (inferior) contracts and conditions stipulated in their homelands rather than in the country where they actually work (Schierup, Andrijasecic, 2010: 136; Apostolova, 2018; Hansen, and Castles, 2006: 34, 152). Legal migrants, including those from EU member states, typically have less access to the welfare state than full citizens enjoy and in most places have neither full voting rights nor freedom from extradition (Bruzelius, Reinprecht, and Seeleib-Kaiser, 2016; Dwyer, Jones and Stewart, 2016; Sainsbury, 2012: 13-31). Furthermore, some visas permit gainful employment while others forbid it (Sainsbury, 2012: 281). Temporary visas can range from several years (for instance, in the process of applying for the permanent visa) or several weeks (in the case of seasonal workers). Temporary visas too can come with severe restrictions. Spouses allowed entry are often denied work permits either permanently or temporarily during a period of probation (Staver, 2013: 61-79). Student visas usually prohibit working in paid jobs and expire upon completion or termination of study (often after a brief grace period). Seasonal and other short-term workers' visas are frequently limited to a specific branch of industry (for example, health services, tourism, agriculture) and sometimes even to a specific employer (for instance, with au pairs). Refugees typically not only have restricted access to social welfare but are usually forbidden to work or else permitted to seek employment only in narrowly stipulated types of work in which they are paid less than the legal minimum wage. Furthermore, refugees are often compelled to reside in specified areas and thus do not enjoy freedom of movement (Gammeltoft-Hansen and Tan 2017: 38; Sainsbury, 2012: 281). Though fully legal and enjoying some but not all the rights of citizenship, these regular migrants are better understood as semi-citizens (Cohen, 2009)

Asylum seekers $(1,300,000$ in 2016, 712,000 in 2017, and 638,000 in 2018) inhabit a veritable no-man's land between legality and illegality. They are neither fully legal nor fully illegal pending a definitive ruling on their application, 871,662 of which were pending at the end of 2018 (Eurostat, 2019a). While waiting (often for years) they are typically denied the right to work and to move freely (Craig, 2013; Hampshire, 2013: 69-76; Scott, 2018), though the EU's Reception Condition Directive (2013) obliges member states to provide some basic services such as emergency healthcare, family unity or children's education (Ataç, 2019). When finally denied asylum (around 558,000 in 2018), many flee authorities and therefore fall into the ranks of the undocumented (European Asylum Support Office, 2019).

\section{Irregular Migration}

Accurate accounts of undocumented migrants in Europe are, needless to say, elusive. The last time it did so, the European Commission (2004: 6) estimated 8 million in 2004. Triandafyllidou and Vogel (2010: 298) put the figure at four million; Minter (2015: 43) between two and four million. Frontex detected 150,114 illegal crossings into Europe in 2018 compared to 214,719 in 2017, 
511,047 in 2016 and 1.82 million in 2015 (Frontex, 2019: 6). Between 1996 and 2008, 22 of the 27 EU states regularised (granted amnesty to) approximately six million migrants lacking fully legal status (Ambrosini, 2015: 201). Others claim that one in ten migrants resides illegally (Bloemraad et al., 2008: 166). The majority (51.1 percent) of known irregular migrants (in 2017) is male between the ages of 18 and 34, though the proportion of women (21.7 percent) and of children (13.1 percent) is expanding (Eurostat, 2019b). Despite the sensational media's spotlight on human trafficking, it seems likely that 75-80 percent of irregular migrants enter with a valid visa of some sort and only later become undocumented by remaining beyond the expiration date (Düvell 2011; Fabini, 2017: 47). As Anderson (2013: 124) perceptively stresses, large numbers of "illegals" are actually semiillegal because they are in semi-compliance rather than full noncompliance with the law (most commonly by residing legally but working illegally). Their statuses can and do change frequently. Consider that in 2011 the countless East Europeans of the so-called EU-8 (states that acceded in 2004) who were residing or working without legal documentation in the EU-15 states became legal overnight. In 2016, Sweden replaced the permanent residence permits with temporary ones (three years) for all but a few thousand refugees transferred through the EU's quota system (Scarpa and Schierup, 2018: 200). Or what of the estimated 3.7 million non-British EU citizens residing in the UK in the case of a hard Brexit (Full Fact, 2019)?

The frequent declarations of amnesty offer insight into the extent of undocumented migration. Especially common in southern Europe in Spain (1985, 1986, 1991, 1996, and 2005), Italy (1987, 1990, 1995, 1998, and 2002), Greece (1998, 2001, 2005, and 2011), and Portugal (2001, 2004, and 2005), but also France (1997) and the Netherlands (2007), amnesties have not only legalised the undocumented (typically only temporarily) but also unofficially encouraged irregular migrants to come or stay in the hope of one day being regularised. It deserves mention that the EU Immigration Pact of 2008 aims to end mass amnesties in all member states.

Needless to say, there exists a critical difference in both quantity and consequence between undocumented aliens in the custody of the state and those at large. However, not all apprehended aliens without proper papers are deported. Many of the nonremoved remain for long periods in detention centers, while others who are notified of an impending deportation abscond before it is carried out (Anderson, 2013: 131-35; Boswell and Geddes, 2011: 171-72). According to Eurostat (2019b), of the 2.2 million persons who were apprehended in the EU in 2015 for not having fully legal documentation 533,000 were ordered to leave the EU. However, only 36 percent (or 194,000) of those ordered to depart actually did so. In 2016, 983,860 persons were apprehended; 493,785 were ordered to exit; 226,150 (46 percent) were returned to their country of origin. In 2017, 618,780 persons were apprehended; 516,100 were ordered to exit; 213,500 (41 percent) were returned to their country of origin.

Deporting persons is not easy. For instance, in any given year, Italy manages to deport only a tenth to a quarter of its deportees (Fabini, 2017: 48). The EU's Dublin System, which stipulates that asylum seekers must be processed in the EU member country that they first entered, actually functions to allow states to tolerate thousands of undocumented asylum-seekers on their sovereign territory, because so few are actually transported back to the country responsible for processing them (Schuster, 2011). The sheer expense of deportations can act as a disincentive. Britain's National Audit Office estimated the cost of deporting a family at $£ 28,000$ and all deportees and their families at $£ 8$ billion (Harding, 2012: 72). Complaining in 2017 that EU member states taken as a whole deport only a third of those designated for deportation, the EU's migration commissioner, Dimitris Avramopoulos, pledged to increase funds for deportations by $€ 200$ million (Deutsche 
Welle 2 February 2017). However, deportations ultimately rely on the police who, with their wideranging street-level bureaucratic discretion, are often more interested in order than formal legality. "If the law distinguishes between documented and undocumented migrants, the police distinguish between troublesome and not troublesome migrants" (Fabini, 2017: 50). It is also well known that many municipal authorities tolerate, serve and even protect undocumented migrants in blatant violation of restrictive national laws (Bauder and Gonzalez, 2018; Spencer and Delvino, 2019).

Even police raids do not, of course, result in the apprehension of all undocumented residents. Rather, the raids serve to force a far greater number to live in the shadows where equal rights are precarious (Inda, 2011: 75; Wyss, 2019). Some scholars go so far as to speak of the "deportation state" where the practice and threat of deportation discipline non-citizens into accepting their underprivileged status (Anderson et al., 2011: 552). Leerkes, Van der Leun and Engbersen (2013: 285), for instance, attribute 28 percent of recorded crimes among undocumented migrants in the Netherlands to "subsistence crime", essentially accepting illegalised employment in order to survive. Likewise, Broeders (2009) found that inadequate documentation, rather than forcing migrants to leave the Netherlands and Germany, more often than not forces them to develop extensive illegal and semi-legal parallel institutions and networks to provide needed services (also Cyrus, 2008; Dimitriadis, 2018; Düvell, 2006; Karakayali, 2015). These, then, are "subcitizens" (Chauvin and Barcés-Mascareñas, 2012: 251) --- persons who regularly reside in Europe but who enjoy few if any of the rights of full citizens.

Not surprisingly, governments denounce both illegal migration and the exploitation of "illegals" and announce high-profile campaigns to eliminate both repugnant phenomena. Thus, the European Commission (2015: 1) adopted the Action Plan against Human Smuggling designed "to prevent the exploitation of migrants by criminal networks and reduce incentives to irregular migration [and] to transform migrant smuggling networks from "low risk, high return" operations into 'high risk, low return' ones".

Nonetheless, both irregular migration and human smuggling persist across Europe. Indeed, they flourish to such an extent that they cannot be explained as rare exceptions to an otherwise uniform and prevailing regularity (Boswell and Geddes, 2011: 131-32; Schierup et al., 2006: 30). It is a well-established fact that southern European economies function through systematic reliance on large numbers of undocumented and semi-legal migrants to fill informal but critical niches in secondary labour markets such as construction, domestic service, hotels, restaurants, agriculture, and retail trade. Estimates put the contribution to GDP in those countries between 25 percent and 40 percent (Van der Leun and Ilies, 2012: 309; also Cheliotis, 2017 and Scrinzi, 2008: 35). Because the workers are typically paid in cash and have no written contracts, employers can intimidate them into accepting salaries and conditions below legal minimums. Small wonder that Greek finance minister Stefanos Manos said in the mid-1990s: "I am enthusiastic about Albanians! It is, of course, illegal work, but this is a precondition for their labour to be provided at a low price" (quoted in Karydis, 2011: 100). Likewise, in 2009, Italy's public service and innovation minister, Renato Brunetta, candidly admitted that the underground economy "plays an important role, especially during an economic crisis" (quoted in Fasani, 2010: 183). The frequent amnesties attest to the integral and regular nature of this labour force (Ángel Brandariz, 2013; Triandafyllidou, 2010).

In what might be termed the "southernisation" of the North, illegalised and semi-legal work have been expanding in northern Europe (Jansen, Celikates, and De Bloois, 2015; Triandafyllidou, 2010). Lest one think, however, that irregular migration represents a novel phenomenon in northern Europe, consider that as early as 1966 France's minister of affairs, Jean Marie Jeanney, remarked 
that "illegal immigration has its uses. [Without it] we would perhaps be short of labour" (quoted in Geddes, 2003: 53). Indeed, it is likely that one third of motorways and one third of automobiles built in France have been constructed by irregular workers (Van der Leun and Ilies, 2012: 309). Though the French amnesty in response to the sans papier movement of 1997 was ostensibly designed to legalise irregular migrants (on average 30,000 annually), Schain (2008: 54) insists that officials deliberately made the mandatory period of documented residency in France prohibitively long (ten years) so as to guarantee that the vast majority of the undocumented would remain so. Ticktin (2006: 33) records the disturbing practice among the sans papiers of injuring themselves as a way to force the state to care for (and thereby regularise) them. Young people who overstay their student visas or accept employment without a work visa add to irregular migration. A British report warns "of producing a generation of disenfranchised youth" (Sigona and Hughes, 2012: vii).

The Dutch government is also known to tolerate large numbers of aliens with insufficient documents. In 2007, it granted amnesty to 28,000 previously rejected but not deported asylum seekers (Van der Leun and Bouter, 2015: 137). Three quarters of Amsterdam's sex workers are thought to be non-nationals among whom four out of five are irregular migrants (Harding, 2012: 122). Moreover, Andrijasevic (2010) found that the vast majority of sex workers in Europe's massive informal sex-trade industry enter European territory legally (for example, as tourists) but take up prostitution out of necessity because they have no work permit or longer-term visa. The state, then, is actually a critical enabling actor despite official campaigns to shut down illegal sex work.

The same is true in the informal market for domestic work (the "three Cs" of cooking, cleaning and caring) which has burgeoned in northwestern Europe (Anderson, 2000; Triandafyllidou, 2013). The German government, for example, all but ensures unlawful domestic labour because it provides no legal means to migrate to Germany as a domestic employee, despite the fact that 11.3 percent of households employ at least one domestic worker (Heimeshoff and Schwenken, 2013: 76). The same holds for the Netherlands, where 13 percent of households employ domestic workers (De Volder, 2017: 147-48). Furthermore, heavy fines exacted by the state for employing undocumented workers in the formal labour sector have the effect of "pushing" migrants into the informal sector, like domestic work, where the fines are not imposed (Van Walsum, 2011: 154). The state, then, operates not merely as a negative agent to reduce the supply of cheap labour (through deportation), but rather far more as a positive agent to increase and guarantee that supply. Thus, "state immigration policies act as an instrumental feature of capital...that increasingly strengthens employers' bargaining power over the local labour force" (Fedyuk and Stewart, 2018b: 8). Lutz and Palenga-Möllenbeck, (2010: 427) claim that the German government's "intentional" nonenforcement of labor laws in the domestic sector represents a "convenient solution" to the growing need "which allocates the risks, duties and costs to individual migrants" [instead of to the state]. Similarly, De Volder (2017: 140) concluded that the Dutch policy "fosters rather than alleviates the vulnerability of domestic workers for THB (trafficking of human beings)". France has twice (2005 and 2012) been sanctioned by the European Court of Human Rights for failing to create a legal and administrative framework that effectively deters and penalises forced domestic labour (Levy 2017: 207).

Predictably, the European Union (EU) denounces the exploitation of undocumented migrants. However, its calls for member states to hold to "universal human rights standards" are non-binding (European Commission, 2003: 26). By contrast, the EU's measures to prevent and prosecute illegal immigration and work are codified in binding regulations (Cyrus, 2008: 183). It is precisely these 
regulations that criminalise countless migrants and essentially normalise irregularity. Indeed, the European Commission has all but conceded so much: "It must be recognised that some illegal migration will take place whatever legal channels are put in place" (European Commission, 2004: 12).

Differential inclusion plays an important role in three critical phenomena that have been developing in neoliberal political economies over the past four decades. European societies have been transforming into "post-Fordist" economies with segmented labor markets that function with an increasing number of precarious ("flexible") forms of employment (especially in the expanding service industries) that provide neither living wages nor benefits for jobholders (Munck et al., 2012; Sassen, 1998; Schierup et al., 2006, Standing, 2011). Concurrently with the emergence of the dual labour market, "post-social" welfare states trim entitlements and increasingly foist the responsibility for one's socioeconomic security onto the individual (Bauman, 2007: 2-4; Rosanvallon, 2013: 20954; Sainsbury, 2012: 113-31). At the same time, structural adjustments imposed on countries of the global South by critical actors in the world economic order, such as the International Monetary Fund and the World Bank, contribute to devastating conditions in those countries that either motivate or compel increasing numbers to (try to) emigrate to the global North (Wills, et al., 2010). These trends combine to spawn a growing minority underclass - a "precariat" (Standing, 2011) - in prosperous countries that is forced permanently to endure living and working conditions systematically and significantly inferior to those of the middle-class majority (Bauman, 2011; Esping-Anderson et al., 2002). Furthermore, "welfare chauvinism," whereby citizens popularly demand inferior welfare benefits for non-citizens, more negatively affects both legalised and illegalised migrants (Rosenberger, 2019). They so disproportionately fill the ranks of this underclass that some authors speak of "an incipient ethno-racial stratification" (Schierup et al., 2006: 81) or even a "European apartheid" (Balibar, 2004: 121). Just as lawmakers know perfectly well from demographers (Organisation for Economic Cooperation and Development, 2013) that Europe depends on immigrants to replace its aging and dwindling population with its low birthrate, they know equally well from political economists and sociologists that their economies, if they are to remain globally competitive, depend on an underclass of modern day "helots" (Cohen, 2006: 152) comprising migrants with varying degrees of (il)legal status. It is estimated, for example, that undeclared work makes up between 11 and 16 percent of GDP in the EU (Van der Leun and Ilies, 2012: 309).

\section{Blocked Migration}

The focus on differential inclusion is not meant to overlook formal exclusion. The EU annually budgets over $€ 100$ million for Frontex (and since 2016 the European Border and Coast Guard) "to reduce the number of irregular migrants entering the EU undetected" (Frontex, 2016). Europe successfully blocks millions from entering its territory. For example, according to the United Nations, only twenty million of the world's 255 million migrants resided in the EU in 2015. Of the estimated 65 million persons displaced from their homes in 2015, 1,046,600 officially reached Europe (UNHCR, 2017a). According to Eurostat (2019b), in 2017, the EU denied entry to 439,505 persons, with Spain $(203,025)$ topping the list followed by France $(86,320)$. Following the example of the United Kingdom, Belgium and Germany in 1987, most European states have since 1990 exacted heavy fines on private passenger carriers (for instance, airlines or cruise ships) that bring inadequately documented persons onto their national territory (Hampshire, 2013: 67). It is important to note that as private companies these carriers are not bound by international asylum and human rights laws such as providing avenues for appeal. Several European governments have also made 
much development aid to poorer countries conditional on the recipient governments' willingness to stem the flow of migration toward Europe in their countries (Frelick, Kysel and Podkul, 2016: 194195 Gammeltoft and Tan 2017: 35-38). Some African countries are known to use brutal methods to comply or to violate the principle of non-refoulement anchored in the 1951 Convention on the Status of Refugees (Davitti et al., 2018). Since 2017, Italy (with EU approval) has indirectly (through the Government of National Accord) paid private militia in Libya to halt refugees using the Libyan route to Europe (Human Rights Watch, 2019). Over 33,000 migrants perished between 1993 and 2017 endeavouring to reach Europe, not to mention those who suffered severe injury or hardship (Tagesspiegel 9 November 2017). It should be noted that the European Court of Human Rights has ruled against some of the tactics of deterrence, for example, in N.D. and N.T. v. Spain (2017) and Hirsi Jamaa v. Italy (2012) (Gammeltoft-Hansen and Tan, 2017: 40-41). Nonetheless, in 2016 alone, 5,096 persons were registered as dead or missing in the Mediterranean Sea; in 2017, 3,139; in 2018, 2,277 (UNHCR, 2019a).

\section{Differential Inclusion and Exclusion}

The concept of differential inclusion provides a more nuanced understanding of Europe's migration regime than the conventional binary distinction between "legal" and "illegal". Various types or degrees of (il)legality are constantly being worked out by vying and allying political actors who wield asymmetrical political power. On a continuum of least to most privileged (in terms of preferring to reside in Europe) several different categories or statuses of inclusion and exclusion stand out. Least privileged are those whose migration to Europe is blocked or thwarted. Within this class, however, significant stratifications exist, for example, between the settled and the displaced. By the end of 2018, one in every 108 persons on the planet was displaced (the highest number ever recorded), 41.3 million inside and 29.4 million outside their own country (UNHCR, 2019b). Many (not all) displaced persons are either officially or unofficially stateless (perhaps as many as 10 million globally) and generally face greater obstacles to legally entering Europe than those in possession of valid passports (Bloom, Tonkiss and Cole, 2017: 3). Additionally, there is the consequential difference between those without and those with loved ones in Europe; the latter likely have better chances and/or rights to reside in Europe or the added benefit of remittances from Europe (approximately thirty billion euros annually) (Eurostat, 2018).

Inside Europe the stratifications through various forms of internal bordering continue. The lives of the illegalised are doubtless precarious, but the conditions and consequences of their precarity vary greatly between those unknown to the state, those known and detained by the state, and those known but not detained (but rather typically ordered to leave but often temporarily tolerated or regularised). Among the nonremoved, access to basic social services can differ among those, for example, with and without serious illness or accompanying family members (Ataç, 2019). The estimated 600,000 stateless persons in Europe vacillate between illegal and legal status because they possess no passport (UNHCR, 2018b). Degrees of precarity vary among legalised migrants as well, for visas differ in terms of type (EU and non-EU or residency, work or study), duration (temporary to permanent), age (maximums for children), marriage (married or divorced), income (enough to support dependents), type of work permitted, and linguistic competence (demonstrated knowledge of dominant language or even culture). The visas typically correspond to very wideranging stipulations for retaining them violations of which, in turn, result in the steady production of semi-legal migrants (Kraler, 2019). Theoretically, full citizens enjoy fully equal rights. However, 
the naturalised (in contrast to those conferred citizenship by birthright) have often had to wait long periods, to pass difficult exams and even to pay expensive fees to obtain citizenship. Furthermore, due to widespread ethnic, religious, racial and gender discrimination de jure citizens often experience radically different de facto citizenship. For example, studies find that Muslims (or people thought to be Muslims) are routinely discriminated against in both the private and public sectors across Europe (Bayrakli and Hafez, 2018). Finally, a number of European countries (the UK, Germany) have begun stripping citizens of their citizenship or confiscating their passports (again here mainly in regard to Muslims alleged to sympathise with the Islamic State) (O'Brien, 2016: 219-223).

Differential inclusion is transforming the model and ideal of citizenship in Europe from one based on equality to one based on stratification. The modern democratic nation-state is normatively rooted in the ideal of equality before the law whereby all persons sharing the same space (governed territory) should have the same rights. However, despite publicly celebrated commitments to this ideal, such as the Racial Equality Directive dedicated to "Implementing the Principle of Equal Treatment between Persons Irrespective of Racial or Ethnic Origin" (Council of the EU, 2000) or The Conclusions of the Tampere European Council to secure for third-country nationals "rights and obligations comparable to those of EU citizens" (Council of the EU, 1999), the fact of the matter is that stratified legal statuses and life experiences are rampant in Europe. European citizens regularly live, work and recreate alongside persons with significantly inferior rights and living conditions in what Lutz and Palenga-Möllenbeck (2010: 419) incisively term an "open secret". Everyday reality resembles more Europe's colonies of the past than the formal democratic ideals of the present (Mezzadra and Neilson, 2013: 155). Sassen (1996: xii and xvii) theorises this development as the simultaneous "denationalizing" of economies (seeking workers globally) and "renationalizing of politics" (legally privileging natives). We can also conceptualise differential inclusion as a "re-medievalisation" of the modern European state and society that revives the kind of hierarchy of ranks common in feudal Europe (O’Brien, 2016: 88).

\section{Assemblage}

Differential inclusion serves as well as harms many interests. Understanding whose interests it serves and how are critical to grasping the permanent, integral (as opposed to temporary, aberrational) character of differential inclusion in the European migration regime. These interests do not reflect those of a highly organised cadre controlled by or in control of the state. Rather, they stem from and are supported by what Foucault (2007: 311) theorised as an "assemblage" of governmentality, that is, a heterogeneous, loosely connected network of people, institutions, discourses, and products that, without central orchestration but with a collective synergy, normatively frames and defines what gets counted (in this case) as "illegal" and "legal" migration, including the best means to regulate them. Applying the concept directly to migration controls in Europe, Bialasiewicz (2012: 844) remarks that "EU border-work...proceeds through a fluid assemblage of functions, mechanisms, and actors; a series of loose institutional arrangements, recomposed in various geometries as 'necessary"'. Furthermore, in an era of globalisation and neoliberalism, nation-states have delegated or relinquished many of their traditional responsibilities for migration control to regional, supranational and international governments (Soysal, 1994) as well as to private NGOs (Gammelhoft-Hansen and Sorensen, 2013). Thus, Frontex (2006: 16) characterises its strategy for "integrated border management" as a "network approach". Moreover, this disaggregation of powers has profoundly complicated and limited the regulation and reform of 
migration practices using conventional means of democratic sovereignty (Butler and Spivak, 2007: 40; Mezzadra and Neilson, 2013: 303).

That said, nation-states are hardly powerless or disinterested. With the growing appeal of the securitisation of immigration - viewing migrants as a threat to national well-being who need to be suspected and policed in various ways (instead of, say, welcomed and assisted) - politicians both holding and seeking power cannot politically afford to neglect the issue. No one (save perhaps the suspected terrorist) represents a more opportunistic target than the "illegal migrant". In 2015, David Cameron warned that a "swarm" of migrants were trying illegally to enter the UK from Calais (Telegraph 15 August 2015); in 2011 Silvio Berlusconi used the term "human tsunami" to refer to those trying to reach EU territory via Lampedusa (Der Spiegel 11 April 2011). Erecting walls, fences and ramparts and ordering raids, detentions and deportations give the appearance that politicians are effectively addressing the issue, even when this is not true (Bauman, 2004: 54). In 2018, for example, Angela Merkel avoided collapse of her government by agreeing with defecting coalition partners to erect detention centers for refugees on Germany's border with Austria. In the same year, the governments of Austria, Hungary, Poland and Croatia refused to sign the United Nations' Global Compact for Safe, Orderly and Regular Migration (2018). By demonising migrants politicians manufacture a soothing sense of national solidarity and even superiority at the very time that globalising trends are undermining such forms of conventional identity (Brown, 2010: 26).

A political paradox has emerged that ensures the continuation of differential inclusion. Despite statements to the contrary, politicians cannot actually want to eradicate irregular migration, lest they lose the very cause célèbre that they so shrewdly exploit. Just this idea of a problem whose solution will always remain elusive comes through in the words of the European Commissioner for Home Affairs, Cecilia Malmström, on the occasion of the fifth anniversary of Frontex in 2010:

It would not be credible to say that all the right tools are here and all the right laws are in place even if we have achieved a lot. The EU needs to commit even more to continue its improvement and be ready to adapt to new challenges in an ever-changing reality. Travel flows are changing. Security threats are evolving (quoted in Feldman, 2012: 15).

Of course, differential inclusion serves economic interests as well. Already mentioned are the myriad ways in which private citizens and businesses profit from regular and irregular migration. They have therefore a strong economic incentive for tolerating and promoting both. Here the focus is primarily but not exclusively on those who benefit from the money allocated for combatting irregular migration, despite the fact that there is neither the political will nor the physical means to eliminate it. As mentioned, the EU annually budgets over $€ 100$ million for Frontex. This figure has increased from $€ 19.1$ in 2006 when Frontex was first established (Feldman, 2012: 72). In addition, the Directorate General for Migration and Home Affairs plans to allocate $€ 6.9$ billion of its $€ 10.52$ budget for 2014-2020 to controlling migration (European Commission, 2018).

Frontex and Home Affairs coordinate but do not replace the member states' own extensive border-control initiatives. Indeed, there are an estimated 400,000 officers in European countries active in border management (Koslowski, 2017: 109-110). To take one example, Spain increased the number of its border agents from 10,239 in 2003 to 16,375 in 2010 (Andersson, 2014: 14). The country's SIVE (Sistema integrado de vigilancia exterior), which uses drones, reconnaissance aircraft, offshore sensors and satellites for detecting and preventing undocumented migration, has become one of the largest surveillance networks in Europe (Wonders, 2017: 15). Moreover, its touted success has spurred many other countries to adopt or emulate it (Andersson, 2014: 85), for 
example, through participation in EUROSUR (the European Border Surveillance System) introduced in 2013-14 in 22 EU states and budgeted with €244 million until 2020 (European Commission, 2013). Roughly the same can be said of EUNAVFOR MED Operation Sophia, in which, since 2015, EU member states cooperate with a variety of sea and air assets to intercept human smuggling rings on the Mediterranean and, since 2016, to train the Libyan navy and coastguard (EUNAVOR MED, 2018).

Governments contract with private companies to design and maintain many of these systems. The cost to maintain the fenced borders surrounding the Spanish enclaves of Cueta and Melilla, to cite one example, is estimated at $€ 10$ million annually (Wonders, 2017: 15). It is worth noting that the EU has more border fencing than the USA (Koslowski, 2017: 109-110). Many of Europe's 400 detention centers for migrants are partially or fully operated by private firms such as G4S (the largest security company in the world), Tascor, Serca, GEPSA, European Homecare, B.O.S.S. Security, ORS, and Swedish Systems Security (Flynn and Cannon, 2009 and Flynn, 2017; also Abrahamsen and Leander, 2016). The EU has massive biometric data processing operations with extensive hardware and software demands. VIS (Visa Information System, until 2012 the Schengen Information System) is thought to be the largest database in the world and cost $£ 760$ million from its inception in 2004 until 2016 (European Commission, 2016: 3). EURODAC, the fingerprinting system for processing applications for asylum, is also massive. European companies vying for the multimillion-euro contracts for these and other projects include SAGEM, Cogent, Gemalto, Leonardo (formerly Finmeccanica), Airbus, Thales, Ericsson, Siemens, Security Network AG, Amper, Isdefe and Indra, not to mention American giants Haliburton, Motorola, Lockheed Martin, and Raytheon (Bigo, 2011: 39; Gameltoft-Hansen and Sorensen, 2013: 4). To give some sense of the scale of the profits to be earned, consider that Trusted Borders (a conglomerate of seven companies) is paid $£ 650$ million to operate the UK’s e-Borders project (Feldman, 2012: 131). The security industry aggressively promotes its interest through powerful lobby groups like the European Organization for Security that forefront and exaggerate the threat stemming from irregular migration (Leander, 2005: 612; Lemberg-Pedersen, 2013; Sanchez, 2017: 12). A close relationship between business and government thrives through industry-government fora such as the European Security Research and Innovation Forum. Small wonder that the European Union's Seventh Framework Programme (FP-7) provided $€ 1.4$ billion for security research between 2007-2013 with the aim of "improving the competitiveness of the European security industry" (quoted in Andersson, 2014: 87). "Horizon 20", the EU's latest innovation and research initiative, allocated just over $€ 1$ billion for 2018-2020 (Moedas and King, 2017: 4)

Security firms surely profit the most, but they are hardly the lone beneficiaries of differential inclusion. Human smugglers, of course, capitalise on the seemingly limitless numbers of persons endeavoring to reach Europe. EUROPOL (2016: 2) estimated that in 2015 alone approximately 40,000 persons earned between $€ 3$ billion and $€ 6$ billion smuggling persons to Europe, even though the average smuggler does not typically earn exorbitant amounts (Sanchez, 2017: 17). A profitable paradox continues to evolve: as the measures to combat irregular migration become more extensive, the smugglers become more sophisticated at eluding them, which in turn enables them to demand higher payments from their clients (Andersson, 2014: 14; Gammelttoft-Hansen and Tan, 2017: 33). Even persons who genuinely want to welcome and assist undocumented migrants rely on differential inclusion, that is, on the persistence of irregular migration and its framing as a "crisis", to justify their efforts. This holds true for the thousands of public officials who service and process illegalised persons (not to mention legal migrants), especially in so-called "sanctuary cities" across 
Europe (Bauder and Gonzalez, 2018). Furthermore, keep in mind that the undocumented are typically counted (estimated) in national censuses from which formulas are derived for allocating public tax dollars. It thus behooves financially strapped municipal and regional governments to tolerate large numbers of irregular migrants (Chauvin and Barcés-Mascareñas, 2012: 254). Similarly and paradoxically, the many non-governmental humanitarian organizations and networks that genuinely assist and advocate for migrants, such as MIGREUROP, CONCORD, No Borders or UNITED, would have neither their cause, their clientele, nor their funding without widespread differential inclusion. The same holds true for journalists and their media organisations, migration lawyers and their firms, researchers and their think tanks and universities all of whom also benefit in various ways from the very problem that they address. The increasing "commercialisation of international migration" (Gammeltoft-Hansen and Sorensen, 2013) would appear to offer nigh limitless ways to profit from the mass movement of human beings that characterises the world today (also Abrahamsen and Leander, 2016; Andersson, 2014; Rodier, 2012).

Finally, sending countries have much to gain from differential inclusion. European states have aggressively pursued what scholars have termed "the externalization" or the "off-shoring" of border control (Frelick, Kysel and Podkul, 2016: 197; Vaughan-Williams, 2008: 67). Through, for example, the Dublin Convention of 1990 or the EU Directive on Minimum Standards on Procedures in Member States for Granting and Withdrawing Refugee Status of 2005, European governments have increased the number of states officially designated "safe third country" from which asylumseekers and undocumented migrants are not accepted (Frelick, Kysel and Podkul, 2016: 206-208). In conjunction with the classification, European states typically negotiate bilateral or multilateral development aid conditioned, however, on using all or some of the aid for financing a full range of border controls in those countries. Thus, quasi-European border controls are established for but not in Europe -- "police à distance" (Bigot and Guild, 2003). Thus, German interior minister Thomas de Maiziere said during his visit to Cairo in 2016 that Egypt is an "indispensable ally... in the battle against irregular migration" (Quantara.de 6 April 2016). In 2008, Italy struck a €5-billion deal (Treaty of Friendship, Partnership and Co-operation) with Libya after Muammar Qaddafi threatened to "turn Europe black" by releasing irregular migrants (quoted in Greenhill, 2016: 330). Likewise, in 2016 Recep Tayyip Erdoğan brokered a €6-billion agreement with the EU after threatening to "open the doors to Greece and Bulgaria and put the refugees on buses" (quoted in Karadağ, 2019). In the same year, deals amounting to $€ 8$ billion were finalised with Sudan, Eritrea, Ethiopia, Jordan, Niger, Nigeria, Lebanon, Mali, Senegal, and Tunisia through the Partnership Framework set forth in the European Agenda on Migration (Scalabrini Migration Study Centers, 2017: 46). Earlier accords with other countries were facilitated through the Cotonou Agreements of 2000 and 2010 or the European Neighbourhood Policy of 2004 and 2015 (Bialasiewicz, 2012: 848-851; Frelick, Kysel and Podkul, 2016: 194-195; Gammeltoft-Hansen and Tan, 2017: 35-38). As mentioned above, such arrangements profoundly transform sovereignty by effectively making European regulations into law in non-European lands (whose peoples have no say in the making of those laws) and, therewith, turning non-European governments into sovereign agents who have minimal if any democratic accountability to European publics.

No one, however, should expect the flow of undocumented workers to stop from sending countries. Remittances from (documented and undocumented) emigrants account for an estimated 2-3 percent of GDP in Algeria and Turkey, 8-10 percent in Morocco (Laurence, 2012: 33; Ahmed, 2012), and 31.1 percent in Tonga, 27.1 percent in Moldova, and 22.5 percent in Bosnia-Herzegovina (Feldman, 2012: 159). The World Bank estimates that migrants transferred approximately $\$ 5$ trillion 
to developing countries between 2000 and 2017. Indeed, total global remittances from richer to poorer countries reached $\$ 443.8$ billion in 2014 compared to $\$ 135$ billion in total governmental development aid (Germano, 2018: 4-5).

\section{Conclusion: Rethinking Sovereignty, Citizenship and Europe}

The conceptual lenses of differential inclusion and assemblage provide a view of European migration that points to the need to rethink conventional notions of sovereignty, citizenship and Europe itself. This rethinking is of such profound magnitude that new directions can only be hinted at here. Full consideration demands separate treatment far beyond the limited scope of this article.

Putative theories of sovereignty (informed by Max Weber in particular) conceptualise sovereignty as power and authority monopolised by the nation-state. Reality is much more complex. Migration and migrants are regulated by a vast array not only of state actors (national but also international, regional and municipal) but also of non-state actors (some for profit, others nonprofit). Such complexity poses grave challenges for democratic accountability. While state officials typically swear an oath to uphold the constitution, non-state actors do not. Indeed, for-profit agents likely bear a fiduciary responsibility to shareholders to maximise profits. How are voters to hold such actors accountable? Perhaps it is time to re-imagine, say, the efforts of migrants to evade capture and detention by Libyan paramilitary organisations, not as a crime, but rather as a legitimate act of political protest on par with, say, an officially permitted demonstration in Rome advocating better rights for migrants.

Who, then, should count as citizens? If this article has demonstrated anything, it is that the customary binary distinction between citizen and non-citizen is inadequate to grasp the complexity of migration. If political subjects are all those over whom political power is exercised, then (wouldbe) migrants without European passports are no less European subjects than those with such passports. If we insist on maintaining the concept of citizen, we should at least take pains to qualify it with terms such as "illegal citizens" (Rigo, 2011: 199), "alien citizens" (Bosniak, 2006), "informal citizens" (Sassen, 2014: 15), "semi-citizens" (Cohen, 2009) or "subcitizens" (Chauvin and BarcésMascareñas, 2012: 251) that illuminate the grades of stratification among persons with varying statuses of (il)legality.

Finally, we should re-imagine what it means to be European. Those without European passports (both in and outside of formal Europe) are "European" in at least two integral ways. First, as mentioned, their lives and life chances are profoundly influenced by European laws and measures. Moreover, this has been true since at least colonial times, what Balibar (2007: 60) calls the "trace of colonization". The European migration regime quite literally assigns a political status to every person on the planet. Even those who do not physically cross into formal Europe are nevertheless critically European because Europe's borders cross or reach them. Europe is not, then, a continental polity, but rather a global one akin to Hardt and Negri's (2000: xii) concept of "Empire" as an "apparatus of rule that progressively incorporates the entire global realm within its...frontiers". According to normative democratic theory, everyone significantly affected by policy should have an equal voice in its making (Carens, 2013). In this light, the European migration regime is profoundly deficient democratically. The perspective focuses attention on "the share of those who have no share" (Ranciere, 1998).

Both legalised and illegalised migrants should also be considered "European" due to the critical contribution that they make to European identity. Conventionally, we think that persons contribute to European identity by, say, speaking certain languages or practicing certain customs. As 
mentioned, borders are performative as well as physical. They are constitutive of identity because it is only possible to define who "We" are by simultaneously defining/marking who is not "We" (Agamben, 2000: 32). The legalised and illegalised migrants enable European identity by being (cast as) the Other that makes Europeanness possible and meaningful. Europe's Others, of course, make this contribution only by being silenced, that is, by being represented rather than being able to represent themselves.

\section{References}

Abrahamsen, R. and Leander, A. (eds.). (2016). Routledge Handbook of Private Security Studies. London: Routledge. https://doi.org/10.4324/9781315850986

Agamben, G. (2000). Means without End: Notes on Politics. Minneapolis: University of Minnesota Press.

Ahmed, F.Z. (2012). "The Perils of Unearned Foreign Income: Aid, Remittances, and Government Survival", American Political Science Review 106 (1): 146-65. https://doi.org/10.1017/S0003055411000475

Ambrosini, M. (2015). "Irregular but Tolerated: Unauthorized Immigration, Elderly Care Recipients, and Invisible Welfare", Migration Studies 3 (2): 196-216. https://doi.org/10.1093/migration/mnu042

Anderson, B. (2000). Doing the Dirty Work: The Global Politics of Domestic Labour. London: Zed Books.

Anderson, B. (2013). Us and Them: The Dangerous Politics of Immigration Control. Oxford: Oxford University Press. https://doi.org/10.1093/acprof:oso/9780199691593.001.0001

Anderson, B., Gibney, M. and Paoletti, E. (2011). "Citizenship, Deportation, and the Boundaries of Belonging", Citizenship Studies 15 (5): 547-63. https://doi.org/10.1080/13621025.2011.583787

Andersson, R. (2014). Illegality, Inc.: Clandestine Migration and the Business of Bordering Europe. Berkeley: University of California Press.

Andrijasevic, R. (2010). Migration, Agency and Citizenship in Sex Trafficking. Basingstoke: Palgrave. https://doi.org/10.1057/9780230299139

Ángel Brandariz, J. (2013). "The Control of Irregular Migrants and the Criminal Law of the Enemy". In M.J. Guia, J. Van Leun, and M. Van der Woude (eds.) Social Control and Justice: Crimmigration in the Age of Fear, pp. 255-266. Leiden: Eleven International Publishing.

Apostolova, R. (2018). "Obstacles before Struggles: Freedom of Movement and the Conditioning of Collective Response". In: O. Fedyuk and P. Stewart (eds.) Inclusion and Exclusion in Europe: Migration, Work and Employment Perspectives, pp. 221-238. London: Rowman and Littlefield.

Ataç, I. (2019). "Deserving Shelter: Conditional Access to Accommodation for Rejected Asylum Seekers in Austria, the Netherlands, and Sweden", Journal of Immigrant and Refugee Studies 17 (1): 44-60. https://doi.org/10.1080/15562948.2018.1530401

Balibar, É. (1998). "The Borders of Europe". In: P. Cheah and R. Robbins (eds) Thinking and Feeling beyond the Nation, pp. 216-229. Minneapolis: University of Minnesota Press.

Balibar, É. (2004). We, the People of Europe? Reflections on Transnational Citizenship. Princeton, NJ: Princeton University Press.

Balibar, É. (2007). "Uprisings in the Banlieues", Constellations 14(1): 47-71. https://doi.org/10.1111/j.14678675.2007.00422.x

Bauder, H. and Gonzalez, D. (2018). "Municipal Responses to 'Illegality': Urban Sanctuary across National Contexts", Social Inclusion 6 (1): 124-134. https://doi.org/10.17645/si.v6i1.1273

Bauman, Z. (2004). Identity: Conversations with Benedetto Vecchi. London: Polity.

Bauman, Z. (2007). Liquid Times: Living in an Age of Uncertainty. Cambridge: Polity.

Bauman, Z. (2011). Collateral Damage: Social Inequalities in a Global Age. Cambridge: Polity.

Bayrakli, E. and Hafez, F. (eds.) (2018). Islamophobia European Report 2017. Istanbul: SETA.

Bialasiewicz, L. (2012). "Off-shoring and Out-sourcing the Borders of Europe: Libya and the EU Border Work in the Mediterranean", Geopolitics 17 (4): 844-866. https://doi.org/10.1080/14650045.2012.660579 
Bigo, D. (2011). "Freedom and Speed in Enlarged Borderzones". In: V. Squire (ed.) The Contested Politics of Mobility: Borderzones and Irregularity, pp 31-50. New York: Routledge.

Bigot, D. and Guild, E. (2003). "Le visa Schengen: expression d'une stratégie de 'police' à distance", Culture and Conflicts 49 (50): 19-33.

Bloemraad, I., Korteweg, A. and Yurdakul, G. (2008). "Citizenship and Integration: Multiculturalism, Assimilation, and Challenges to the Nation-state", Annual Review of Sociology 34: 153-79. https://doi.org/10.1146/annurev.soc.34.040507.134608

Bloom, T., Tonkiss, K. and Cole, P. (2017). "Introduction". In T. Bloom, K. Tonkiss and P. Cole (eds.) Understanding Statelessness, pp. 1-14. London: Routledge. https://doi.org/10.4324/9781315200460-1

Bosniak, L. (2006). The Citizen and the Alien: Dilemmas of Contemporary Membership. Princeton, NJ: Princeton University Press. https://doi.org/10.1515/9781400827510

Boswell, C. (2003). European Migration Policies in Flux: Changing Patterns of Inclusion and Exclusion. Oxford: Blackwell. https://doi.org/10.1002/9780470752845

Boswell, C. (2007). "Theorizing Immigration Policy: Is There a Third Way?" International Migration Review 41 (1): 75-100. https://doi.org/10.1111/j.1747-7379.2007.00057.x

Boswell, C. and Geddes, A. (2011). Migration and Mobility in the European Union. Basingstoke, U.K.: Palgrave. https://doi.org/10.1007/978-1-137-28548-5

Broeders, D. (2009). Breaking Down Anonymity: Digital Surveillance of Irregular Migrants in Germany and the Netherlands. Amsterdam: Amsterdam University Press. https://doi.org/10.5117/9789089641595

Brown, W. (2010). Walled States, Waning Sovereignty. New York: Zone Books.

Bruzelius, C., Reinprecht, C. and Seeleib-Kaiser, M. (2016). "EU Migrant Citizens, Welfare States and Social Rights". Paper presented at the 23rd Conference of the Council for European Studies. Philadelphia, 14-16 April.

Carens, J. (2013). The Ethics of Immigration. Oxford: Oxford University Press.

Chauvin, S. and Barcés-Mascareñas, B. (2012). "Beyond Informal Citizenship: The New Moral Economy of Migrant Illegality", International Political Sociology 6 (3): 241-259. https://doi.org/10.1111/j.17495687.2012.00162.x

Cheliotis, L. (2017). "Punitive Inclusion: the Political Economy of Irregular Migration in the Margins of Europe", European Journal of Criminology 14 (1): 78-99. https://doi.org/10.1177/1477370816640137

Cohen, E. (2009). Semi-citizenship in Democratic Politics. Cambridge: Cambridge University Press. https://doi.org/10.1017/CBO9780511642333

Cohen, R. (2006). Migration and Its Enemies. Aldershot, U.K.: Ashgate. https://doi.org/10.7551/mitpress/3311.001.0001

Cornelius, W. A., and Tsuda, T. (2004). "Controlling Immigration: the Limits of Government Intervention". In: W.A. Cornelius, et al. (eds.) Controlling Immigration: A Global Perspective, pp. 3- 48. Stanford: Stanford University Press.

Council of the EU (1999). "Tampere European Council 15 and 16 October 1999: Conclusions of the Presidency". Available at https://www.cvce.eu/en/obj/conclusions_of_the_tampere_european council_15_and_16_october_1999-en-32135242-b375-47fe-adb4-e02ab2432945. html; accessed 23 May 2018 .

Council of the EU. (2000). "Council Directive 2000/43/EC of 29 June 2000 Implementing the Principle of Equal Treatment between Persons Irrespective of Racial or Ethnic Origin". Official Journal of the European Communities, L 180, 19.7.

Craig, S. (2013). "Struggling with EU Safe Country Practices in Asylum". In U. Korkut, et al. (eds.) The Discourses and Politics of Immigration in Europe, pp. 53-72. New York: Palgrave. https://doi.org/10.1057/9781137310903_4

Cyrus, N. (2008). "Being Illegal in Europe: Strategies and Policies for Fairer Treatment of Migrant Domestic Workers". In H. Lutz (ed.) Migration and Domestic Work: A European Perspective on a Global Theme, pp. 177-194. Burlington: Ashgate. 
Davitti, D., Fries, M. and Walter-Franke, M. (2018). "Gradations of Externalization: Is the EU Sailing towards Offshoring Asylum Protection?" FMU Policy Brief, 3/2018. 17 May.

De Genova, N. (2015). "Extremities and Regularities: Regulatory Regimes and the Spectacle of Immigration Enforcement". In: Y. Jansen, R. Celikates and J. de Bloois (eds.) The Irregularization of Migration in Contemporary Europe, pp. 3-14. London: Rowman Littlefield.

De Volder, E. (2017). "Trafficking in the Domestic-Work Sector in the Netherlands: A Hidden Phenomenon", $\begin{array}{lllllll}\text { Journal of Immigrant and Refugee } & \text { Studies } 15 & \text { (2): }\end{array}$ https://doi.org/10.1080/15562948.2017.1307479

Düvell, F., ed. (2006). Illegal Immigration in Europe: Beyond Control? New York: Palgrave. https://doi.org/10.1057/9780230555020

Düvell, F. (2011). "Paths into Irregularity: The Legal and Social Construction of Irregular Migration", European Journal for Migration and Law 13(3): 275-95. https://doi.org/10.1163/157181611X587856

Dimitriadis, Iraklis. (2018). "'Asking Around': Immigrants' Counterstrategies to Renew Their Residence Permit in Times of Economic Crisis in Italy." Journal of Immigrant and Refugee Studies 16 (4): 275-292. https://doi.org/10.1080/15562948.2016.1273433

Dwyer, P., Jones, K. and Stewart, A. (2016). "Diminished Citizenship: The Impact of Restricted Welfare Rights on the Lives of A8/A2 Migrants in the UK". Paper presented at the 23rd Conference of the Council for European Studies. Philadelphia, 14-16 April.

Esping-Andersen, G., Gallie, D., Hemerijck, A. and Myles, J. (2002). Why We Need a New Welfare State. Oxford: Oxford University Press. https://doi.org/10.1093/0199256438.001.0001

EUNAVOR MED (2018). "Operation Sophia." Available at https://www.operationsophia.eu/about-us/; accessed 15 May 2018.

European Asylum Support Office. (2019). "Latest Asylum Trends - 2018 Overview." Available at https://www.easo.europa.eu/asylum-trends-overview-2018; accessed 30 June 2019.

European Commission (2000). On a Community Immigration Policy. Brussels: Commission of the European Communities.

European Commission (2003). On Immigration, Integration and Employment. COM (2003) 336 final. Brussels: European Commission.

European Commission (2004). Study on the Link between Legal and Illegal Migration. COM (2004) 412 final. Brussels: European Commission.

European Commission (2013). "EUROSUR: New Tools to Save Migrants' Lives at Sea and Fight Crossborder Crime". 19 June. Brussels. Available at http://europa.eu/rapid/press-release_MEMO-13578 en.htm; accessed 17 September 2017.

European Commission (2015). EU Action Plan against Migrant Smuggling (2015 - 2020). COM (2015) 285 final. Brussels: European Commission.

European Commission (2016). Report from the Commission to the European Parliament and the Council on the implementation of Regulation (EC) No 767/2008 of the European Parliament and of the Council establishing the Visa Information System (VIS). COM (2016) 655 Final. Brussels: European Commission.

European Commission (2018). "Migration and Home Affairs: Financing". Available at https://ec.europa.eu/home-affairs/financing_en, accessed 23 May 2018.

EUROPOL (2016). "Migrant Smuggling in the EU". February. Available at file://C:/Users/pobrien/Downloads/migrant_smuggling_europol_report_2016\%20(2).pdf; accessed 26 June 2019.

Eurostat. (2018). "Personal Remittances Statistics". Available at https://ec.europa.eu/eurostat/statisticsexplained/index.php/Personal_remittances_statistics\#EU-28_is_a_net_payer_in_personal_remittances_ to_the_rest_of the_world_again; accessed 22 June 2019.

Eurostat (2019a). "Assylum Statistics". Available at https://ec.europa.eu/eurostat/statisticsexplained/ index.php/Asylum_statistics\#Decisions_on_asylum_applications; accessed 30 June 2019. 
Eurostat (2019b). "Statistics on Enforcement of Immigration Legislation." Available at https://ec.europa.eu/eurostat/statistics-explained/index.php/Enforcement_of_immigration__ legislation_ statistics\#Latest_trends_in_enforcement_statistics; accessed 26 June 2019.

Fabini, G. (2017). "Managing Illegality at the Internal Border: Governing through Differential Inclusion in Italy", European Journal of Criminology 14 (1): 46-62. https://doi.org/10.1177/1477370816640138

Fasani, F. (2010). "The Quest for La Dolce Vita? Undocumented Migration in Italy". In: A. Triandafyllidou (ed.) Irregular Migration in Europe: Myths and Realities, pp.167-186. Farnham, U.K.: Ashgate.

Feldman, G. (2012). The Migration Apparatus: Security, Labor, and Policymaking in the European Union. Stanford: Stanford University Press.

Fedyuk, O. and Stewart, P. (eds.) (2018a). Inclusion and Exclusion in Europe: Migration, Work and Employment Perspectives. London: Rowman and Littlefield.

Fedyuk, O. and Stewart, P.(2018b). "Introduction: Migrants' Inclusion and Exclusion in the Context of Precarization of Working Lives in Post-Enlargement EU." In O. Fedyuk and P. Stewart (eds.) Inclusion and Exclusion in Europe: Migration, Work and Employment Perspectives, pp. 1-14. London: Rowman and Littlefield.

Flynn, M. and Cannon, C. (2009). "The Privatization of Immigration Detention: Towards a Global View". Global Detention Project Working Paper No.1. Global Detention Project. September. Available at https://papers.ssrn.com/sol3/papers.cfm?abstract_id=2344196; $\quad$ accessed 26 June 2019. https://doi.org/10.2139/ssrn.2344196

Flynn, M. (2017). Statement to the Working Group on the Use of Mercenaries Panel on "PMSCs in Places of Deprivation of Liberty and their Impact on Human Rights". Geneva: Global Detention Project.

Foucault, M. (2007). Security, Territory, Population: Lectures at the College de France, 1977-78. New York: Palgrave.

Frelick, B., Kysel, I. and Podkul, J. (2016). "The Impact of Externalization of Migration Controls on the Rights of Asylum Seekers and Other Migrants", Journal on Migration and Human Security 4 (4): 190220. https://doi.org/10.1177/233150241600400402

Frontex (2016). "Mission and Tasks". Available at http://frontex.europa.eu/about-frontex/mission-and-tasks/; accessed 13 August 2015.

Frontex (2019). Risk Analysis for 2019. Warsaw: Frontex.

Full Fact. (2019). "EU Immigration to the UK". 18 March.

Gammeltoft-Hansen, T. and Sorensen, N. N. (2013). "Introduction". In: T. Gammeltoft-Hansen and N.N. Sorensen (eds.) The Migration Industry and the Commercialization of International Migration, pp. 1-23. New York: Routledge.

Gammeltoft-Hansen, T. and Tan, N. (2017). "The End of the Deterrence Paradigm? Future Directions for Global Refugee Policy", Journal on Migration and Human Security 5 (1): 28-56. https://doi.org/10.1177/233150241700500103

Geddes, A. (2003). The Politics of Migration and Immigration in Europe. London: Sage. https://doi.org/10.4135/9781446280492

Germano, R. (2018). Out Sourcing Welfare: How the Money Immigrants Send Home Contributes to Stability in Developing Countries. New York: Oxford University Press.

Greenhill, K. (2016). "Open Arms behind Barred Doors: Fear, Hypocrisy and Policy Schizophrenia in the European Migration Crisis", European Law Journal 22 (3): 317-332. https://doi.org/10.1111/eulj.12179

Hampshire, J. (2013). The Politics of Immigration: The Contradictions of the Liberal State. Oxford: Polity.

Harding, Jeremy. 2012. Border Vigils: Keeping Migrants Out of the Rich World. London: Verso.

Heimeshoff, L. and Schwenken, H. (2013). "Three Different Things: Having, Knowing and Claiming Rights: Undocumented Immigrant Domestic Workers in Germany". In: A. Triandafyllidou (ed) Irregular Migrant Domestic Workers in Europe: Who Cares?, pp. 71-94. Farnham, U.K.: Ashgate.

Human Rights Watch. (2019). "No Escape from Hell: EU Policies Contribute to Abuse of Migrants in Libya". 21 January. Available at https://www.hrw.org/report/2019/01/21/no-escape-hell/eu-policies-contributeabuse-migrants-libya\#page; accessed 1 July 2019. 
Inda, J. (2011). "Borderzones of Enforcement: Criminalization, Workplace Raids, and Migrant Counterconducts". In: V. Squire (ed.) The Contested Politics of Mobility: Borderzones and Irregularity, pp. 74-90. New York: Routledge.

Isin, E. (2018). "Mobile Peoples: Transversal Configurations", Social Inclusion 6 (1): 115-123. https://doi.org/10.17645/si.v6i1.1304

Jansen, Y., Celikates, R. and De Bloois, J. (2015). "Introduction". In: Y. Jansen, R. Celikates, and J. De Bloois (eds.) The Irregularization of Migration in Contemporary Europe: Detention, Deportation, Drowning, pp. ix-xxv. London: Rowman and Littlefield.

Karadağ, S. (2019). "Extraterritoriality of European Borders to Turkey: An Implementation Perspective of Counteractive Strategies", Comparative Migration Studies 7 (12). https://doi.org/10.1186/s40878-0190113-y

Karakayali, S. (2015). "Illegal Migration in Post-Fordism.". In: Y. Jansen, R. Celikates, and J. De Bloois, (eds.) The Irregularization of Migration in Contemporary Europe: Detention, Deportation, Drowning, pp. 31-54. London: Rowman and Littlefield.

Karydis, V. (2011). "Immigration and Crime". In: L. Cheliotis and S. Xenakis (eds) Crime and Punishment in Contemporary Greece: International Comparative Perspectives, pp. 87-109. Bern: Peter Lang.

Koslowski, R. (2017). "Addressing Side-Effects of Increasing Border Security Cooperation: A Global Perspective". In: F. Pastore (ed.) Beyond the Migration and Asylum Crisis: Options and Lessons for Europe, pp. 108-114. Rome: Aspen Institute Italia.

Kraler, A. (2019). "Regularization of Irregular Migrants and Social Policies: Comparative Perspectives", Journal of Immigrant and Refugee Studies 17 (1): 94-113. https://doi.org/10.1080/15562948.2018.1522561

Laurence, J. (2012). The Emancipation of Europe's Muslims: The State's Role in Minority Integration. Princeton, NJ: Princeton University Press. https://doi.org/10.23943/princeton/9780691144214.001.0001

Leander, A. (2005). "The Market for Force and Public Security: The Destabilizing Consequences of Private Military Companies", Journal of Peace Research 42 (5): 605-622. https://doi.org/10.1177/0022343305056237

Leerkes, A., Van der Leun, J. and Engbersen, G. (2013). "Crime among Irregular Immigrants and the Influence of Crimmigation Processes". In: M. Guia, J. Van der Leun, and M. Van der Woude (eds.) Social Control and Justice: Crimmigration in the Age of Fear, pp. 267-288. Leiden: Eleven International Publishing.

Lemberg-Pedersen, M. (2013). "Private Security Companies and the European Borderscapes" In: T. Gammeltoft N. and Sorensen (eds.) The Migration Industry and the Commercialization of International Migration, pp. 152-172. New York: Routledge.

Levy, F. (2017). "French Government Responses against Trafficking in the Domestic Work Sector: Denial or Political Priority?" Journal of Immigrant \& Refugee Studies 15 (2): 204-219. https://doi.org/10.1080/15562948.2017.1305474

Lutz, H. and Palenga-Möllenbeck, E. (2010). "Care Work Migration in Germany: Semi-compliance and Complicity", Social Policy and Society 9 (3): 419-430. https://doi.org/10.1017/S1474746410000138

Mezzadra, S. and Neilson, B. (2013). Border as Method: Or, the Multiplication of Labor. Durham: Duke University Press. https://doi.org/10.1215/9780822377542

Minter, S. (2015). Irregular Immigration: An Economic Analysis of Policies in the EU. Tübingen: Mohr Siebeck. https://doi.org/10.1628/978-3-16-152951-1

Moedas, C. and King, J. (2017). Security Research and Innovation: Boosting Effectiveness of the Security Union. Brussels: European Commission.

Munck, R., Schierup, C. and Wise, R. (2012). "Migration, Work, and Citizenship in the New World Order". In: R. Munck, C. Schierup, and R. Wise (eds.) Migration, Work and Citizenship in the New Global Order, pp. 1-12. London: Routledge. https://doi.org/10.4324/9780203722770

Nail, T. (2015). The Figure of the Migrant. Stanford: Stanford University Press. 
O'Brien, Peter. (2016). The Muslim Question in Europe: Political Controversies and Public Philosophies. Philadelphia: Temple University Press. https://doi.org/10.26530/OAPEN_605456

Organisation for Economic Cooperation and Development (2013). International Migration Outlook 2013. Paris: OECD.

Rancière, J. (1998). Dis-Agreement: Politics and Philosophy. Minneapolis: University of Minnestoa Press. Rigo, E. (2011). "Citizens despite Borders: Challenges to the Territorial Order of Europe." In: V. Squire (ed.) The Contested Politics of Mobility: Borderzones and Irregularity, pp. 199-215. New York: Routledge.

Rodier, C. (2012). Xénophobie Business: À quoi servent les contrôles migratoires? Paris: La Découverte.

Rosanvallon, P. (2013). The Society of Equals. Cambridge, MA: Harvard University Press. https://doi.org/10.4159/harvard.9780674726444

Sainsbury, D. (2012). Welfare States and Immigrant Rights: The Politics of Inclusion and Exclusion. Oxford: Oxford University Press. https://doi.org/10.1093/acprof:oso/9780199654772.001.0001

Rosenberger, S. (2019). "Navigating the Representative-Politics-Liberal Rights Dilemma: Social Policy Designs for Nonremoved Migrants", Journal of Immigrant and Refugee Studies 17 (1): 11-26. https://doi.org/10.1080/15562948.2018.1489089

Sanchez, G. (2017). "Critical Perspectives on Clandestine Migration Facilitation: An Overview of Migrant Smuggling Research", Journal on Migration and Human Security 5 (1): 9-27. https://doi.org/10.1177/233150241700500102

Sassen, S. (1996). Losing Control? Sovereignty in an Age of Globalization. New York: Columbia University Press.

Sassen, S. (1998). Globalization and Its Discontents: Essays on the New Mobility of People and Money. New York: The New Press.

Sassen, S. (2014). "Anti-Immigrant Politics along with Institutional Incorporation"? in Walton-Roberts, M. and Hennebry, J. (eds.), Territoriality and Migration in the E.U. Neighborhood: Spilling over the Wall, pp. 13-28. Dordrecht: Springer. https://doi.org/10.1007/978-94-007-6745-4_2

Scalabrini Migration Study Centers. (2017). International Migration Policy Report. New York: Center for Migration Studies.

Scarpa, S. and Schierup, C-U. (2018). "Who Undermines the Welfare State? Austerity-Dogmatism and the U-Turn in Swedish Asylum Policy", Social Inclusion 6 (1): 199-207. https://doi.org/10.17645/si.v6i1.1285

Schain, M. (2008). The Politics of Immigration in France, Britain, and the United States. New York: Palgrave. https://doi.org/10.1057/9780230616660

Schierup, C., Hansen, P. and Castles, S. (2006). Migration, Citizenship, and the European Welfare State. Oxford: Oxford University Press. https://doi.org/10.1093/0198280521.001.0001

Schuster, L. (2011). "Engendering Insecurity: The EU Asylum Regime". In: G. Lazaridis (ed.) Security, Insecurity and Migration in Europe, pp. 101-118. Farnham: Ashgate.

Scott, P. (2018). "It's Like Fighting for Survival": How Rejected Black African Asylum Seekers Experience Living Conditions in an Eastern German State", Journal of Immigrant and Refugee Studies 16 (4): 372 390. https://doi.org/10.1080/15562948.2017.1316534

Scrinzi, F. (2008). "Migrations and the Restructuring of the Welfare State in Italy: Change and Continuity in the Domestic Work Sector". In: H. Lutz (ed.) Migration and Domestic Work: A European Perspective on a Global Theme, pp. 29-42. Burlington: Ashgate.

Sigona, N. and Hughes, V. (2012). No Way Out, No Way in: Irregular Migrant Children and Families in the UK. Oxford: ESRC Centre on Migration, Policy and Society, Oxford University.

Soysal, Y. (1994). Limits of Citizenship: Migrants and Postnational Membership in Europe. Chicago: University of Chicago Press.

Spencer, S. and Delvino, N. (2019). "Municipal Activism on Irregular Migrants: The Framing of Inclusive Approaches at the Local Level" Journal of Immigrant and Refugee Studies 17 (1): 27-43. https://doi.org/10.1080/15562948.2018.1519867

Squire, V. (2011). The Contested Politics of Mobility: Borderzones and Irregularity. New York: Routledge. 


\section{Bordering in Europe: Differential Inclusion}

Standing, G. (2011). The Precariat: The New Dangerous Class. London: Bloomsbury Academic.

Staver, A. (2013). "Free Movement of Workers or Citizens? Reverse Discrimination in European Family Reunification Policies". In: W. Maas (ed.) Democratic Citizenship and the Free Movement of People, pp. 57-89. Leiden: Martinus Nijhoff. https://doi.org/10.1163/9789004243286_006

Ticktin, M. (2006). "Where Ethics and Politics Meet: The Violence of Humanitarianism in France", American Ethnologist 33 (1): 33-49. https://doi.org/10.1525/ae.2006.33.1.33

Triandafyllidou, A. (ed.) (2010). Irregular Migration in Europe: Myths and Realities. Farnham, U.K.: Ashgate.

Triandafyllidou, A. (ed.) (2013). Irregular Migrant Domestic Workers in Europe: Who Cares? Farnham, U.K.: Ashgate.

Triandafyllidou, A. and Vogel, D. (2010). "Irregular Migration in the European Union: Evidence, Facts and Myths". In: A. Triandafyllidou (ed.) Irregular Migration in Europe: Myths and Realities, pp.291-99. Farnham, U.K.: Ashgate.

UNHCR (United Nations High Commissioner for Refugees). (2017a). "UNHCR's Strategic Directions 20172021". Available at http://www.unhcr.org/en-us/excom/announce/5894558d4/unhcrs-strategicdirections-2017-2021.html; accessed 10 February 2017).

UNHCR (United Nations High Commissioner for Refugees). (2018a). "Global Trends: Forced Displacement in 2018". Available at http://www.unhcr.org/5b27be547; accessed 2 November 2018.

UNHCR (United Nations High Commissioner for Refugees). (2018b). "Statelessness Around the World". Available at https://www.unhcr.org/en-us/statelessness-around-the-world.html

UNHCR (United Nations High Commissioner for Refugees). (2019a). "Desperate Journeys: Refugees and Migrants Arriving in Europe and at Europe's Borders". Available at https://data2.unhcr.org/en/documents/download/67712; accessed 27 June 2019.

UNHCR (United Nations High Commissioner for Refugees). (2019b). "Global Trends: Forced Displacement in 2018". Available at https://reliefweb.int/sites/reliefweb.int/files/resources/5d08d7ee7_0.pdf; accessed 2 November 2018.

Van der Leun, J. and Bouter, H. (2015). "Gimme Shelter: Inclusion and Exclusion of Irregular Immigrants in Dutch Civil Society", Journal of Immigrant \& Refugee Studies 13 (2): 135-55. https://doi.org/10.1080/15562948.2015.1033507

Van der Leun, J. and Ilies, M. (2012). "Undocumented Migration: An Explanatory Framework". In: M. Martiniello and J. Rath (eds.) An Introduction to International Migration Studies: European Perspectives, pp. 305-328. Amsterdam: University of Amsterdam Press. https://doi.org/10.2307/j.ctt6wp6qz.16

Van Walsum, S. (2011). "Regulating Migrant Domestic Work in the Netherlands: Opportunities and Pitfalls", Canadian Journal of Women and the Law 23/1: 141-165. https://doi.org/10.3138/cjwl.23.1.141

Vaughan-Williams, N. (2008). "Borderwork beyond Inside/Outside? Frontex, the Citizen-detective and the War on Terror", Space and Polity 12 (1): 63-79. https://doi.org/10.1080/13562570801969457

Vertovec, S. (2016). Super-diversity. London: Routledge.

Wills, J., et al. (2010). Global Cities at Work: New Migrant Divisions of Labour. London: Pluto.

Wonders, N. (2017). "Sitting on the Fence - Spain's Delicate Balance: Bordering, Multiscalar Challenges, and Crimmigation", European Journal of Criminology $14 \quad$ (1): 7-26. https://doi.org/10.1177/1477370816640140

Wyss, A. (2019). "Stuck in Mobility? Interrupted Journeys of Migrants with Precarious Legal Status in Europe", Journal of Immigrant and Refugee Studies 17 (1): 77-93. https://doi.org/10.1080/15562948.2018.1514091 